Данилова Екатерина Олеговна, директор;

Фетисов Андрей Александрович, методист учебной части, Филиал ФГБВОУ ВО «Военно-медицинская академия имени С.М. Кирова» Медищинский колледж, 2. Москва, Россия

МЕТОДИЧЕСКИЕ РЕКОМЕНДАЦИИ ДЛЯ ПРОВЕДЕНИЯ КОНКУРСА ТВОРЧЕСКИХ РАБОТ СТУДЕНТОВ МЕДИЦИНСКОГО КОЛЛЕДЖА «МЕДИЦИНА БУДУЩЕГО-2018»

\title{
GUIDELINES FOR ORGANIZING AND CONDUCTING A COMPETITION OF CREATIVE WORKS AMONG THE STUDENTS OF THE MEDICAL COLLEGE «MEDICINE OF THE FUTURE-2018»
}

Материалы, изложенные в статье, могут быть рекомендованы для проведения конкурса творческих работ среди студентов медицинских колледжей.

Ключевые слова: медицинский колледж, конкурс творческих работ, медицина будущего.

\section{Хронологическая карта мероприятия:}

1. Раньше это казалось фантастикой (бредом) ... (видео-превью к конкурсу) - 2 мин.

2. «Мир стареет в былых надеждах ...» (пролог) - 1 мин.

3. Введение, цели, задачи - 5 мин.

4. Представление жюри, счетной комиссии и др. - 5 мин.

5. Представление команд - 2 мин.

6. Условия конкурса, критерии оценки - 5 мин.

7. Выступление команд - 50 мин.

8. Подсчет результатов (Предсказания от Google / Поживём, увидим) - 5 мин.

9. Объявление результатов: награждение призеров, лауреатов - 10 мин. 
«Наука и образование: новое время» № 1, 2019

10. Слово гостям. Рефлексия - 10 мин.

11. Закрытие конкурса - 2 мин.

\section{Слайд 2.}

Гаснет свет. Музыка (2:10-3:10).

На фоне:

Мир стареет в былых надеждах.

Но сегодня, как и вчера,

На себе эту землю держат

И несут на себе мастера!

Мастера - профессионалы,

Те, что в жизни постичь смогли

Щедрость камня, душу металла,

Свежесть формулы, нрав земли.

Мастера, мастаки, умельцы!

Понимающие до глубин

Механизмы станка или сердца,

Ход смычка или гул турбин...

Руки вещие простирая

Перекрёсткам звёздных миров,

Время движется мастерами

И надеется на мастеров!

\section{Слайд 3.}

Видео-превью (2 мин.) Сейчас нам уже не верится, что их открытия прежде были гранью фантастики и прорывом в будущее!

\section{Слайд 4.}


Давайте уже сегодня начнем менять своё будущее! Встанем плечом к плечу с прогрессом, разумом, творчеством и ринемся в будущее с великой наукой, имя которой - Медицина!

\section{Слайд 6.}

Добрый день, уважаемые участники, коллеги, гости!

Мы рады видеть каждого из Вас на конкурсе творческих работ студентов «Медицина будущего»!

Сегодня мы говорим «Здравствуйте!» всем, кого согревает тепло научной мысли, творческое вдохновение, жажда поиска и жажда открытий. Сегодня в наших умах и душах царствуют науки.

Несомненно, этот конкурс объединит сегодня всех стремящихся к творческому и научному поиску.

\section{Слайд 7.}

Итак, иель нашего конкурса: представить возможность каждому студенту реализовать свое право на творческое развитие в соответствии с его способностями, задать траекторию развития его талантов, профессионального роста, расширения кругозора, а также привить интерес к постижению медицинских наук.

\section{Слайд 8. Порядок проведения конкурса.}

- Участие в Конкурсе принимают студенты 1 курса, обучающиеся по специальности 34.02.01 Сестринское дело.

- В конкурсе принимают участие 8 команд. Каждая команда самостоятельно представит своё название и девиз.

- Наш конкурс стартовал 03 октября. Студентам было предложено принять участие в конкурсе творческих проектов. Срок реализации проекта составил 2 месяца. За это время участники должны были придумать название команды и девиз, выбрать направление проектной деятельности, разработать макет проекта и подготовить его презентацию. 
«Наука и образование: новое время» № 1, 2019

- Каждая команда сегодня в течение 5 минут представит свой творческий проект.

• По результатам выступления каждой команды по окончании конкурса будут названы победитель и призёры.

\section{Слайо 9.}

Оценивать наш конкурс будет компетентное жюри (оглашаются ФИО председателя жюри и его членов).

Подсчеты и объявление результатов выступления команд будет осуществлять счетная комиссия конкурса (оглашаются ФИО членов счётной комиссии).

За соблюдением всех регламентов конкурса будет следить уважаемая экспертная комиссия (оглашаются ФИО членов экспертной комиссии).

\section{Слайо 10.}

Теперь предлагаю всем ознакомимся с критериями оценки конкурсных проектов и выступления команды:

1) самостоятельность выполнения - 0-2 балла (оценивается, насколько проект выполнен своими руками без помощи сторонних организаций или типографий);

2) соответствие проекта теме конкурса - 0-2 балла (проект носит медицинскую тематику в перспективе будущего);

3) регламент времени на защиту - 0-2 балла:

2 балла - выступление команды до 5 минут;

1 балл - выступление команды 5-7 минут;

0 баллов - выступление команды более 7 минут.

Если выступление продолжается более 8 минут, прозвучит звуковой сигнал, после которого команда должна завершить своё выступление и занять места в зале.

4) презентабельность проекта - 2 балла (насколько проект готов к защите и может быть представлен на суд общественности); 
«Наука и образование: новое время» № 1, 2019

5) сложность исполнения (трудоемкость) - 2 балла:

рисунок, схема - 1 балл,

модель, макет - 2 балла;

6) актуальность - 1 балл (насколько проект может быть востребован в настоящее время в практическом здравоохранении согласно мнению жюри):

да - 1 балл,

нет - 0 баллов;

7) функциональность - 1 балл (сколько одновременно функций может выполнять представленный проект):

да - 1 балл.

нет - 0 баллов

8) реалистичность - 1 балл (может ли проект быть выполнен сегодня):

да - 1 балл,

нет - 0 баллов;

9) оригинальность - 2 балла (насколько проект неповторим):

да -1 балл

нет - 0 баллов.

Максимальное количество баллов за участие - 15.

Также каждая команда может получить дополнительные баллы, если представит своё название - 1 балл; свой девиз - 1 балл.

Следует отметить следующее: если установлен факт плагиата материалов проекта из сети Интернет или установлен факт наличия одинаковых фрагментов в конкурсных работах двух и более команд, то в этом случае участники теряют оценочные баллы и не могут быть объявлены победителями Конкурса.

Жюри имеет право добавить 5 бонусных баллов наиболее понравившейся команде, также жюри может воспользоваться этим правом при возникновении спорной ситуации, а именно при равном количестве баллов у двух команд.

\section{Слайд 11.}


Итак, настало время конкурса.

Мы приглашаем к защите своего проекта Команду под номером 1. Время пошло.

Команда под номером 1 завершила своё выступление. Мы просим вас занять места в зале. Членов жюри мы просим заполнить оценочные листы и передать их в счетную комиссию.

Команда под номером 8 завершила своё выступление. Мы просим вас занять места в зале. Членов жюри мы просим заполнить оценочные листы и передать их в счетную комиссию.

Пока счетная комиссия подводит итоги выступления команд, мы хотели бы услышать мнение членов жюри о представленных студенческих проектах. Спасибо за Ваши слова.

А каково мнение экспертов о представленных студенческих проектах и о выступлении команд в целом? Участникам будет особо интересно его услышать. Спасибо, уважаемые эксперты за Ваши точки зрения.

А сейчас мне бы хотелось обратиться к учащимся 3-го курса.

- Каково Ваше мнение о сегодняшних выступлениях команд? Ведь два года назад Вы так же принимали участие в конкурсе «Медицина будущего», поэтому этот конкурс мы могли бы назвать «Медицина будущего, версия 2.0».

- Как Вам выступления команд?

- Как Вы оцениваете представленные проекты?

Спасибо за Ваши мнения.

А есть ли желание поделиться впечатлениями о своем выступлении в конкурсе у наших участников - студентов 1 курса?

Спасибо за Ваши точки зрения.

\section{Слайд 12.}


«Наука и образование: новое время» № 1, 2019

Итак, когда последние подсчеты произведены, мы просим председателя жюри поделиться с нами своими впечатлениями об увиденном, озвучить окончательные результаты конкурса и наградить победителей и призеров конкурса «Медицина будущего».

\section{Слайд 13.}

Спасибо Вам за Ваши слова и пожелания, на этом позвольте нам поблагодарить всех участников, членов жюри, экспертов и гостей конкурса.

Спасибо всем за внимание! Мы желаем каждому из Вас всего самого доброго, творческих успехов и надеемся на скорую встречу! До свидания!

СПИСОК ЛИТЕРАТУРЫ

1. Положение о проведении конкурса творческих работ «Медищина будущего-2018» среди студентов медицинского колледжа филиала Военно-медицинской академии имени С.М. Кирова.

2. Рождественский Р.И. Стихотворения. М.: Эксмо, 2007.

3. http://uznay-kak.ru

4. https://www.kakprosto.ru

5. https://страначиталия.pф 